Araştırma Makalesi - Research Article

\title{
Türkiye'de Özel Sağlık Sigortacılığı Sisteminin Mevcut Durum Analizi
}

\section{Current Situation Analysis of Private Health Insurance System in Turkey}

\author{
Ekrem SEVİ* \\ (iD) 0000-0003-0697-5899 \\ Mustafa NAL ${ }^{* *}$ \\ (iD) 0000-0002-3282-1124 \\ ÖZ
}

Özel sağlık sigortaları, sağlı hizmetlerinin finansmanında kullanılan en önemli yöntemlerden biridir ve ülkelerin sağlık politikalarına göre sistem içerisinde kendisine yer bulmaktadır. Türkiye, sağlık sistemi içerisinde özel sağlık sigortasına yer verme açısından, gelişmiş ülkelere oranla oldukça geridedir. Bu durum Türkiye'nin sosyal bir sağlık politikası izlemesi ile açılanabilir. Özel sağlık sigortaları genellikle, özel sağlık kuruluşlarının SGK kapsamı dışında sunduğu hizmetlerden faydalanmak isteyen bireyler tarafindan tercih edilmektedir. Yapılan çalışmanın amacı, Türkiye'de özel sağlık sigortacılığının SWOT analizi vasıtasıyla mevcut durumunun analiz edilmesidir. Bu amaca ulaşabilmek için Delphi yönteminden faydalanılmış ve çalışma on kişilik bir uzman grubu ile yürütülmüştür. Çalışma bulguları incelendiğinde, Türkiye'nin özel sağlık sigortacılığg açısından; güçlü yönlere dair 7, zayıf yönlere dair 13, firsatlara dair 9 ve tehditlere dair 10 ifadeden oluşan mevcut duruma dair bir analiz ortaya çıkmıştır. En güçlü yön olarak, düşük bekleme süresi ile kaliteli hizmet sunumu gösterilirken, müşterilerin özel sağlık sigortası hakkında yeterli bilgiye sahip olmaması en önemli zayıf yön olarak ortaya çıkmıştır. İnsanların sağlıklarına önem vermeleri, sektörün büyümeye açık olması ve sigortacılık konusunda eğitici kurum sayısının artması en önemli firsatlar olarak değerlendirilmiş, kamu hastanelerinde verilen hizmetlerin büyük bir kısmının GSS kapsamında olması ve özel sağlık sigortası sisteminin giderlerin tamamını karşılamıyor olması en önemli tehditler olarak ortaya çıkmıştır.

Anahtar Sözcükler: Özel sağlık sigortası, sağlık sistemi, SWOT analizi, delphi yöntemi
Sosyal Güvenlik Dergisi / Journal of Social Security

ilt: 11 Sayı: 1 Y1l: 2021 /Volume: 11 Issue: 1 Year: 2021

Sayfa Aralığı: 157-174 / Pages: 157-174

OI: $10.32331 /$ sgd.952573

\section{ABSTRACT}

Private health insurances are one of the most important methods used in the financing of health services and they find a place in the system in different ways according to the health policies of countries. In Turkey, the weight in the system of private health insurance is very low compared to developed countries. This could be explained by Turkey's social health policy monitoring. In addition, individuals who want to benefit from the services provided by private health institutions outside the scope of SGK prefer private health insurance. The aim of the study carried out by the SWOT analysis is to analyze the current situation of private health insurance in Turkey. Delphi method was used to achieve this goal. In this context, the study was conducted with an expert group of ten people. When the study findings are examined in terms of Turkey's private health insurance; A current situation analysis was conducted consisting of 7 strengths, 13 weaknesses, 9 opportunities and 10 threat statements. While low waiting times and quality service delivery were shown as the strongest aspects, the lack of sufficient information about private health insurance emerged as the most important weakness of the customers. The most important opportunities are that people care about their health, the industry is open to growth, and the number of educational institutions on insurance is increasing. The fact that most of the services provided in public hospitals are covered by GHI and the private health insurance system does not cover all expenses emerged as the most important threats.

Keywords: Private health insurance, health system, SWOT analysis, delphi method

Önerilen atıf șekli: Sevim, E. ve Nal, M. (2021). Türkiye'de Özel Sağlık Sigortacılığı Sisteminin Mevcut Durum Analizi. Sosyal Güvenlik Dergisi (Journal of Social Security). 11(1). 157-174

• Geliş Tarihi/Received: 17/02/2021 • Güncelleme Tarihi/Revised: 06/06/2021 • Kabul Tarihi/Accepted: 14/06/2021

\footnotetext{
* Dr. Öğr. Üyesi, Bandırma Onyedi Eylül Üniversitesi, Sağlık Bilimleri Fakültesi, Sağlık Yönetimi Bölümü, esevim@bandirma.edu.tr

** Dr. Öğr. Üyesi, Afyon Kocatepe Üniversitesi, Dinar Uygulamalı Bilimler Yüksekokulu,

Sigortacılık ve Aktüerya Bilimleri Bölümü, mustafanal@aku.edu.tr
} 


\section{GíRIŞ}

Sağlıklı yaşamak her insanın en temel hakkıdır. Bu nedenle bireylerin sağlık bütünlüğü bozulduğunda tedavi olmak istemesi yani sağlığına kavuşmak istemesi en doğal hakkıdır. Ancak tedavi olmanın finansal açıdan bir bedeli vardır. Bu bedel genellikle cepten ödemeler yoluyla ya da sağlık sigortaları tarafından ödenerek karşılanmaktadır. Bazı durumlarda alınan sağlık hizmetlerinin ücretlerini karşılamak bireyleri finansal açıdan zorlayabilmektedir. Bu sebeple günümüzde sağlık sigortası insanlar için önemli bir ihtiyaç haline gelmiştir. Modern sağlık sistemlerinde hizmetlerin finansmanı için, hizmet sunucusu ile hizmeti alan taraf arasında doğrudan bir finansal akış yerine, daha sıklıkla üçüncü taraf bir ödeyici finansman rolünü üstlenmektedir. Bunun temel sebebi, sağlık hizmetlerinin kullanımının rastlantısal olması ve ihtiyacın ortaya çıktığı durumda katlanılacak maliyetin belirsiz olmasıdır (Tatar, 2011: 105). Çünkü insanların ne zaman kaza geçireceğini veya hastalanacağını bilmek mümkün olmadığı gibi bu olaylar meydana geldiğinde tanı ve tedavi masraflarını karşılayacak maddi kaynakların yetersiz olma olasılığı da vardır. Sağlık sigortası sayesinde insanlar gelecekte toplu olarak ödenme ihtimali olan sağlık hizmeti bedellerine kıyasla, daha düşük olan sağlık sigortası primlerini önceden ödeyerek, kendilerini finansal açıdan güvence altına almaktadırlar.

Türkiye'de ikamet eden herkes sosyal güvenlik kapsamında yer almakta, ancak insanlar farklı nedenlerden dolayı özel sağlı sigortalarından yararlanma tercihinde bulunabilmekteler. Türkiye Cumhuriyeti'nin On Birinci Kalkınma Planında, sigortacılık ve sağlık sigortacılığı ile ilgili bazı hedeflere yer verilmiştir. Bunlar; tamamlayıcı sağlık sigortasını geliştirmeye yönelik grup poliçeleri için işverene avantajlar sağlanması, Türkiye reasürans havuzunun faaliyete geçirilmesi; 2018 y1lında \%85,6 olan sosyal sigorta kapsamının 2023 yılında \%95'e çıkarılması, sosyal sigorta prim tabanının genişletilmesi, sisteme girişin kolaylaştırılması ve denetimler yoluyla sistemin etkinleştirilmesi, katılım sigortacılığını teşvik edici mahiyette mevzuat ve kurumsal yapının geliştirilmesi ve her tür risk grubuna hitap edecek şekilde yaygınlaştırılması, 2018 yılında \%4 olan SGK'ya yapılan bütçe transferlerinin GSYH'ya oranının 2023 yılında \%3,2'ye düşürülmesi, 2018 yılında $\% 82,9$ olan toplam prim tahsilat oranının 2023 yılında \%88,1'e çıkarılması gibi hedefler belirlenmiştir (T.C. Cumhurbaşkanlığı, 2019: 51).

Türkiye’de özel sağlık sigortacılığı sektörünün yıldan yıla büyüdüğü görülmektedir. Özel sağlık sigortacılığının geleceği hakkında öngörüde bulunabilmek için mevcut durumun analizinin yapılmasının faydalı olacağı düşünülmektedir. Yapılan araştırmada, Türkiye'de özel sağlık sigortacılığı için "fırsatlar nelerdir, tehditler nelerdir, zayıf ve güçlü yanlar nelerdir" sorularının yanıtları bulunmaya çalışılmıştır. Literatürde Türkiye'de özel sağlık sigortacılığının mevcut durumunu analiz eden bir çalışmaya rastlanmamıştır. Bu araştırma literatürdeki bu eksikliği gidermek amacı ile yapılmıştır.

\section{I- KAVRAMSAL ÇERÇEVE}

\section{A- Sağlık Sigortası}

İnsan var olduğundan bu yana tehlikelerle karşılaşmış ve bu tehlikelere karşı bir güvence arayışı içinde olmuştur. Özellikle sanayileşme dönemi sonrasında, kentleşmenin artması ve sosyo-ekonomik gelişmeler sonucunda bazı risk faktörleri önem kazanmış ve insanlar bu risklere karşı bazı önlemler geliştirmişlerdir (Ateş, 2011: 22). Bu risklerden biri de sağlı̆̆ın bozulma riskidir ve buna karşı bir güvence olarak sağlık sigortası uygulaması geliştirilmiştir.

Dünyada modern anlamda ilk sağlık sigortası uygulaması 1848 yılında Londra'da demiryolu işçilerine uygulanmıştır. Daha sonra 1883 yılında Almanya'da, 1887'de Avusturya'da, 
1891'de Macaristan'da, 1894'te Norveç ve Fransa'da, 1895'te Finlandiya'da, 1898'de İtalya'da, 1900'de İspanya'da, 1901'de Hollanda, Lüksemburg ve İsveç'te sağlık sigortas1 ile ilgili kanunlar çıkarılmıştır (Ateş, 2011: 23). Türkiye'de ise sağlık sigortası kapsamında ilk uygulama 1921 yılında çıkarılan, kazazede ve hasta maden işçilerini bakım güvencesi altına alan "Havza-i Fahmiyye Amele Kanunu” dur (Karakök, 2011: 351).

Sağlık sigortası, bireyin hastalık veya kaza geçirmesi sonucunda, hekim muayene, teşhis, tedavi, ameliyat, ilaç gibi sağlık hizmetleri giderlerini karşılamaya yönelik teminat veren sigorta türüdür (Ateş, 2011: 22). Sağlık sigortasının teminat kapsamında hem hastalık durumu hem de kaza sonucu oluşabilecek yaralanmalar yer almaktadır (Orhaner, 2018: 176). Sağlık sigortası olan bireyler ödedikleri prim karşılığında hastalık veya kazaya uğradıklarında kendilerine verilen sağlık hizmetlerinin finansmanına katkı sağlamış olurlar (Orhaner, 2018: 114).

Sağlık sigortası ile sigortacının sigortalı bireye verdiği teminatlar aşağıdaki gibidir (Orhaner, 2018: 177):

- Hastalık hali nedeni ile gerekli olan ilaç, tıbbi bakım, gebelik ve doğum, erken tanıya yönelik verilen sağlık hizmetleri dâhil olmak üzere sözleşmede belirtilen giderler,

- Yatarak tedavi verilen durumlarda günlük hastane giderleri,

- Hastalık sonucu iş göremezlik nedeni ile elde edilemeyen kazançlar için kararlaştırılan günlük iş görememe ücreti,

- Sigortalının bakıma muhtaç olması durumunda, bakım giderleri veya kararlaştırılan gündelik parası.

Sağlık sigortası programları için üç ana finansman kaynağından söz edilebilir: toplanan vergilerle finansman (Beveridge Modeli), sosyal güvenlik primleri ile finansman (Bismark Modeli) ve özel sağlık finansmanıdır. İlk iki model kamu sağlık sigortaları olarak şekillenirken, özel sağlık sigortası (ÖSS) modeli bireylerin özel olarak yaptırdıkları özel sağlık sigortalarının primlerini, kendilerinin ödemeleri ve tıbbi tasarruf hesaplarını içermektedir (OECD, 2004: 8). Ülke sağlık sistemleri de bu modellerin yoğun olarak kullanım durumuna göre şekillenmektedir. Birçok ülke sağlık hizmetlerinin finansmanı kapsamında farklı yöntemleri birlikte kullanmaktadır. Örneğin genel vergilerle finansmanın yapıldığı en tipik sağlık sistemine sahip olan İngiltere'de özel sağlık sigortası, cepten ödemeler ve sosyal sigorta modeli ana sistemine ek olarak uygulanmaktadır (Tatar, 2011: 104). Sağlık sigortası, sigorta teminatı veren kurum yönünden temel olarak iki grupta incelenebilir. Birincisi kamu (devlet) tarafindan sunulan "kamu sağlık sigortası", ikincisi ise özel şirketler tarafından sunulan "özel sağlık sigortası” dır.

\section{B- Özel Sağlık Sigortacılığı}

Türkiye'de özel bir şirket tarafından 1938 yılında gemi kurtarma çalışmalarında görevli işçilere hastalık sigortası türünde teminat verilmeye başlanmıştır (Ateş, 2011: 25). Bu uygulama ile Türkiye'de ilk kez özel sağlık sigortası faaliyete geçmiştir. Türkiye Sigorta Birliği istatistiklerine göre Türkiye'de 2017 yılında 36 olan özel sağlık sigortası hizmeti veren şirket sayısı \%25 artışla, 2019 yılında 45'e ulaşmıştır (Türkiye Sigorta Birliği, 2019: 21).

Özel sağlık sigortası, sigorta süresi içerisinde, poliçe şartlarında belirtilen durumlar sonucunda meydana gelen kaza ve hastalık hali ile ilgili olarak ortaya çıkan tedavi giderlerinin, poliçede belirtilen limit dâhilinde sigorta şirketinin katılım payı oranında ve sigortalının muafiyet tutarı kısmı dışında ödeme yapılan sigorta türüdür (Ateş, 2011: 30; 
Tunc ve Mithat, 2015: 441). Özel sağlık sigortaları, genellikle devletin sunmuş olduğu hizmetlere ek ya da tamamlayıcı nitelikte olmakta ve bu sayede devletin yükünü azaltıcı etkisi bulunmaktadır (Ateş, 2011: 24).

Türkiye'de ikamet eden herkes 2012 yılından itibaren zorunlu genel sağlık sigortası kapsamına alınmıştır (Koçkaya, Atikeler ve Yenilmez, 2016: 86; Orhaner, 2018: 12). Sosyal güvenlik şemsiyesi altında bulunan ancak sağlık hizmeti konusunda beklentileri karşılanmayan (Ateş, 2011: 37) veya farklı nedenlerden dolayı özel hastanelerden hizmet almak isteyen bireyler olabilmektedir. Bazı özel hastanelerin Sosyal Güvelik Kurumu ile anlaşması olmayabilmekte veya verilen hizmet bedellerinin tamamı Sosyal Güvenlik Kurumu tarafindan karşılanmayabilmektedir. Özel hastanelerden hizmet almak isteyen ve giderlerinin sigorta tarafından karşılanmasını isteyen insanlar, özel sağlık sigortasına ihtiyaç duymaktadır. Özel sağlık sigortaları bu ihtiyacı karşılamak amacıyla, özel hastaneler ile bu hastanelerden hizmet almak isteyen bireyler arasındaki bağlantıyı sağlamaktadırlar (Ateş, 2011: 37).

Sağlıkta dönüşüm programı sonrası devlete bağlı tek geri ödeme kuruluşu olan SGK, topladığı prim ve maliyetleri belirlemektedir. Ayrıca geri ödeme kuruluşu olarak ilaç, tıbbi cihaz ve yatış maliyetleri gibi hizmet sunum maliyetlerini de belirlemektedir. Bu sadece kendi maliyetlerini düşürmenin yanında, muhtemelen özel sağlık sigorta kuruluşlarının maliyetlerini de etkilemiştir (Koçkaya, Atikeler ve Yenilmez, 2016: 83).

Türkiye'de 2018 yılı sonu itibari ile özel sağlık sigortasından faydalanan 2.200.000 kişi (ferdi=1.000.000, grup=1.200.000), tamamlayıcı sağlı sigortasından faydalanan 920.000 (ferdi=363.000, grup=557.000) kişi olmuştur. Özel sağlık sigortası ve tamamlayıcı sağlık sigortasından faydalanan bireyler ile bu sayı toplam 3.120.000 kişi olmuştur. Bu verilere göre Türkiye'de nüfusun \%3,8'i özel sağlı sigortası ve tamamlayıcı sağlık sigortasından faydalanmaktadır (Türkiye Sigorta Birliği, 2018: 31). Şirket sayısında da son dönemde artış gözlenmektedir. 2014 yılında 34 olan şirket sayısı da 2018 yılında \%32'lik artışla 45'e yükselmiştir (Türkiye Sigorta Birliği, 2019: 21).

Türkiye'de özel sağlık sigortacılığının toplam sağlık harcamaları içerisindeki payı yaklaşık \%2 olup, bu oran diğer ülkelere göre oldukça düşüktür (Deloitte, 2015: 69). Sağlık hizmetlerinin finansmanının devlet güvencesi kapsamında sunulduğu Almanya'da bu oran \%10 olarak gerçekleşmektedir. Fransa ve Kanada'da \%14, Birleşik Krallık'ta ise \%15 civarında gerçekleşmektedir (Arora, Charlesworth, Kelly ve Stoye, 2013: 9).

Tablo 1'de Türkiye'de yıllara göre özel sağlı sigortası prim büyüklüğü gösterilmektedir. 2014 yılı prim miktarı ile 2019 yılı prim miktarı arasındaki artış \%285 olarak gerçekleşmiştir. Bu durum özel sağlık sigorta sisteminin yıllar içerisindeki gelişimini göstermektedir.

Tablo 1. Türkiye'de Yıllara Göre Özel Sağlık Sigortası Prim Miktarı

\begin{tabular}{ccc}
\hline Y1l & Özel Sağlık Sigortası Prim Miktarı & Artış Oranı (\%) \\
\hline 2014 & 2.929 .632 .073 & 18,5 \\
\hline 2015 & 3.435 .938 .626 & 17,3 \\
\hline 2016 & 4.226 .366 .352 & 23,0 \\
\hline 2017 & 5.024 .664 .774 & 18,9 \\
\hline 2018 & 6.245 .415 .184 & 24,3 \\
\hline 2019 & 8.358 .916 .934 & 33,8 \\
\hline
\end{tabular}

Kaynak: (Türkiye Sigorta Birliği, 2019: 22-23) 
Özel sağlık sigortası modelini sağlık sisteminde ana finansman kaynağı olarak kullanan ülkeler için en uygun örnek Amerika Birleşik Devletleri'dir (Tatar, 2011: 111). Türkiye'de özel sağlık sigortası sektörü \%2'lik oranı ile Fransa (\%14), Kanada (\%14), İngiltere (\%15) gibi gelişmiş ülkelere göre sınırlı kalmaktadır. Bu durumun sebepleri arasında; sosyal devlet anlayışı çerçevesinde kamu tarafından sunulan geniş kapsamlı hizmet, eğitim ve gelir durumu yüksek olan gruplar (AB grubu) ile sınırlı kalması, kamudan alınan hizmetten memnuniyet düzeyi, çoğu durumda erişimde sorun yaşanmaması ve özel sağlık sigortasının lüks olarak görülmesi gösterilmektedir (Özsarı ve Güdük, 2020: 527-528).

\section{C- Delphi Metodu}

Delphi metodu 1950'li yıllarda RAND firmasının Normal Darkey ve Olaf Helmer adında iki çalışanı tarafından askeri alanda yapılacak olan araştırmalarda uzun dönemli tahminlerin yapılmasında kullanılmak amacıyla geliştirilmiştir (Dalkey ve Helmer, 1962: 1; Erffmeyer, Erffmeyer ve Lane, 1986: 120; Yurt ve Kadığlu, 2019: 49). Adı ise antik Yunan'daki Delphi dağından gelmektedir. Bu adı almasının sebebi ise dağda yaşayan kâhinlerin gelecek ile ilgili kehanetlerde bulunmaları olarak bilinmektedir (Yiğit ve Şeker, 2016: 70). Delphi metodu, üzerinde çalışılan konu ile ilgili olarak yeterli bilgi sahibi olduğu düşünülen bir grup uzmanın görüş birliğine varmalarını sağlayan bir çeşit uzlaşı yöntemidir (Dalkey ve Helmer, 1962: 1; Jenkins ve Smith, 1994: 3; Yiğit ve Şeker, 2016: 70). RAND firması düşünürlerinin Delphi yöntemini geliştirirken önlerinde; gelecekteki teknolojilerin askeri alandaki potansiyelinin tespit edilmesi ve potansiyel siyasi meseleler ile bunların çözüm yollarının neler olabileceğinin belirlenmesi konuları bulunuyordu (Gordon, 1994: 1; Jenkins ve Smith, 1994: 3). Yöntem, belirlenen uzman grubun belli bir konu hakkındaki görüşlerinin sistematik olarak elde edilmesi ve birleştirilmesi sürecini içermektedir (Jenkins ve Smith, 1994: 3).

Delphi tekniği karar almayı kolaylaştıran bir süreçtir. Temelde "belli bir konuda birçok görüş ve düşünce tek bir görüşten daha anlamlıdır" ilkesine dayanmaktadır (Yurt ve Kadıoğlu, 2019: 49). Delphi yönteminin en önemli avantajları arasında; uzman olarak belirlenen grupta yer alan her bir bireyin uygulama aşamasında birbiri hakkında bilgi sahibi olmaması ve bunun sonucunda da yeni fikir beyan etme ve ifade edilen fikre katılıp katılmama özgürlüğünün olması sayılabilir. Bu sayede ilgili alanda daha fazla söz sahibi olmayı sağlayan; akademik unvan, baskın kişilik yapıları ve ilgili konuda grup içerisinde yüksek statü sahibi kişilerin bulunması gibi diğer uzmanların rahat fikir beyan etmelerini engelleyebilecek unsurların ortadan kaldırılma olanağı elde edilmektedir. Bu durum yeni fikirlerin belirtilmesinin yanında eleştirilere de uygun ortam sağlamaktadır (Gordon, 1994: 3).

Yöntemin uygulanma aşamasında belirlenen uzman gruba daha önceden belirlenmiş olan ifadeler gönderilerek, ifadeleri değerlendirmeleri ve varsa belirledikleri yeni ifadeleri eklemeleri istenebilir. Daha sonrasında her bir ifade için grup ortalama puanı her bir uzmana bildirilerek kendi puanı ile karşılaştırma imkânı sağlanır. Bu aşama her bir ifade üzerinde uzlaşı sağlanıncaya kadar birden fazla kez tekrarlanabilir (Gordon, 1994: 10). Literatürde ideal tekrar sayısının 2 ya da 3 olarak alınabileceği (Erffmeyer, Erffmeyer ve Lane, 1986: 126), 2 tur ya da yeterli olmaması durumunda uzlaşı sağlanıncaya kadar tekrarlanabileceği (Brown, 1968: 6) ifade edilmiştir.

Genel olarak Delphi yönteminin bir çeşit tartışma olduğu söylenebilir. Bu sayede belirlenen bir grup uzmanın konu hakkındaki ortak bakış açısına ulaşılmış olur (Gordon, 1994: 3). Delphi yöntemi ile bir pazarın gelecekteki büyüklügü ve bir hedefe ulaşmak için uygun politika belirlenmesi dâhil olmak üzere konu üzerinde muhakeme ve tahmin gerektiren herhangi bir konuda çözüme destek sağlanabilir (Brown, 1968: 2; Şahin, 2001: 215). 
Delphi yönteminin genel olarak üç özelliğinden bahsedilebilir. Bunlar; katılımda gizlilik, grup kararının analizi ve kontrollü geri besleme olarak sayılabilir. Katılımda gizlilik yöntemin en belirgin özelliği olarak sayılabilir. $\mathrm{Bu}$ sayede bireyler birbirlerinden etkilenmeden ve özgürce fikirlerini belirtebilir. Dolayısıyla bireylerden çok farklı fikirler ön plana çıkar. Grup kararının analizi aşamasında ortaya koyulan yeni ifade ve bu ifadelere ait puanlar değerlendirilir. Kontrollü geri besleme adımında ise her bir uzman kendi ifadesi ve puanının yanında grup kararını da gözlemlemeyebilir. Bu sayede konu hakkında yeni fikirlerin özgürce ortaya çıkması sağlanırken, üzerinde çalışılan konuya ilişkin bir uzlaşıya da varılabilir (Şahin, 2001: 216).

\section{D- SWOT Analizi}

SWOT analizi kişi, kurum ya da organizasyonların, stratejik yönetim araçlarından biridir (Ajmera, 2017: 369; Çoban ve Karakaya, 2010: 347). Bu yöntem ile yapıların; rekabet gücü, zayıf yönleri, dış piyasadaki fırsat ve tehditlerine yönelik değerlendirmeler yapılabilir. Bu iç ve dış faktörler sırasıyla; güçlü yönler, zayıf yönler, fırsatlar ve tehditlerden oluşmaktadır (Hill ve Westbrook, 1997: 47; Shahabi, Basiri, Kahag ve Zonouzi, 2014: 9).

SWOT analizinin amacı, kişi, kurum ya da organizasyon için içsel ve dışsal faktörlerini de göz önünde bulundurarak, mevcut güçlü yönler ve firsatlardan maksimum seviyede yararlanmayı, aynı zamanda olası tehdit ve zayıf yönlerin etkilerinin minimuma indirilmesine yönelik çeşitli plan ve stratejilerin geliştirilmesidir (Ervural, Zaim, Demirel, Aydın ve Delen, 2018: 3; Shahabi, Basiri, Kahag ve Zonouzi, 2014: 19; Yüksel ve Dağdeviren, 2007: 3364).

Mevcut durum analizi uygun soruların sorulmasıyla elde edilebilir. İç ve dış çevre analizinin yapılmasından sonra, gelecek durum analizi yapılır. Bu sayede mevcut durum ile gelecek arasında bağ kurularak geleceğe yönelik stratejiler planlanabilir (Helms ve Nixon, 2010: 216). SWOT analizinde mevcut durumun analizi yapılırken en yaygın yöntemlerden birisi uzman görüşünün alınmasıdır. Delphi yöntemi ile birlikte kullanımına sıklıkla rastlanmaktadır (Gürel ve Tat, 2017: 1003).

\section{E- Literatür Özeti}

Türkiye'de özel sağlık sigortası sektörünün gelişmiş ülkelere göre daha sınırlı bir büyüklügünün olması, akademik yayınların sayısına da yansımaktadır. Yapılan literatür taramalarında çalışmaların belirli konularla sınırlı kaldığı gözlenmiştir. Bu kapsamda; özel sağlık sigortacılığı sisteminin gelişim süreci ve mevcut durumu, bireylerin bu konudaki algıları ve bireylerin sigorta tercihini etkileyen faktörlere dair çalışmaların yapıldığı görülmektedir. Yapılan çalışmalar içerisinde sektörün stratejik olarak analizinin yapıldığı bir çalışmaya rastlanmamıştır. Stratejik analiz yöntemlerinden biri olan SWOT analizinin, katılımcıların uzlaşısına dayanan Delphi yöntemi ile ele alındığı bu çalışma, diğer çalışmalardan farklılık göstermektedir.

Tatar (2011: 111) tarafından sağlık hizmetlerinin finansman modelleri ile ilgili olarak sosyal sağlık sigortası modelinin Türkiye'deki gelişiminin incelendiği bir çalışma yürütülmüştür. Yapılan çalışmada, sosyal sigorta ile özel sağlık sigortası modellerine dair bazı temel çıkarımlarda bulunulmuştur. En belirgin fark olarak, sosyal sigorta modelinde bireylerin riskleri ve sağlık statüleriyle ödenecek primler arasında herhangi bir ilişkinin olmamasına karşın, özel sağlık sigortası modelinde bireylerin sağlık statülerinin düşmesi ve risklerin artmasının, ödenecek primleri de artırdığı ifade edilmiştir.

Kamilçelebi (2012: 53) tarafından Türkiye'deki sigorta sektörünü genel olarak anlamaya yönelik bir çalışma yürütülmüştür. Yapılan çalışmada sektörün durumu incelenmiş ve genel olarak toplumun sektöre yaklaşımının istenilen düzeyde olmadığı, yetişmiş insan gücünün 
sayı ve nitelik olarak sınırlı kaldığı ifade edilerek bu eksikliklere yönelik çeşitli önerilerde bulunulmuştur.

Orhaner (2017: 411) tarafından Türkiye'de özel sağlık sigortacılığı sisteminin gelişmesi için yapılabilecek düzenlemelerle ilgili yapılan çalışmada, nüfusun artması, bireylerin sağlık duyarlılıklarının artması ve kişi başı gelirin artması ile yapılabilecek bazı düzenlemeler sayesinde özel sağlık sigortalarına olan talebin artabileceği ifade edilmiştir. $\mathrm{Bu}$ talebin artması için sektörün indirim ve muafiyet gibi bazı özendirici uygulamalar yapması önerilmektedir.

Özsarı ve Güdük (2020: 527) tarafından, özel sağlık sigortacılığının mevcut durumu, sorunları, gelişimi için neler yapılması gerektiği ve sektörü gelecekte nelerin beklediğine dair bir çalışma yapılmıştır. Çalışma sonucunda sektörün gelişmiş ülkelere oranla daha az geliştiği ve bu durumun ortaya çıkmasını ise Türkiye'nin uyguladığı politikaların bir sonucu olduğu belirtilmiştir. Bu çerçevede; sağlık hizmetlerinin sosyal devlet anlayışı çerçevesinde değerlendirilerek kamu tarafından geniş kapsamlı olarak sunumunun yanında, bireylerin kamu sağlık tesislerinde sunulan hizmetten genel olarak memnun olması ve erişimde sorun yaşanmaması önemli etkenler olarak gösterilmiştir. Ayrıca özel sağlık sigortası tercihinin; üst gelir grupları ile sınırlı kalması ve lüks bir tercih olarak görülmesi durumun ortaya çıkmasında etken olduğu gösterilmiştir.

Tapan, Alıcı, Yıldırım ve Gayef (2015: 85) tarafından tamamlayıcı sağlık sigortası tercihlerinin incelendiği bir çalışma yürütülmüştür. Özel sağlık sigortası temsilcileri ile yapılan çalışmada, katılımcıların \%93'ü tamamlayıcı sağlık sigortasını, genel sağlık sigortasının sürdürülebilirliği açısından önemli ve birlikte kullanılmasının sektörün geleceği için gerekliliği sonucuna ulaşılmıştır. Benzer şekilde, Özer (2015: 167) tarafından sektör temsilcileri ile yapılan bir çalışmada, katılımcıların \%37,35'inin özel sağlık sigortası türlerinden biri olan tamamlayıcı sağlık sigortasına olumlu bir gelişme olarak yaklaştıklarını ve sektörün finansal sürdürülebilirliğine katkı sunabileceğini düşündükleri sonucuna ulaşmıştır.

Balkanlı (2017: 62) tarafından, Türkiye ve dünyada özel sağlık sigortacılığının incelenmesine yönelik yapılan çalışmada, özel sağlık sigortasının tamamlayıcı olarak genel sağlık sistemine entegre edilmesinin daha uygun bir yöntem olduğu belirtilmiştir. Bu kapsamda da genellikle ülkelerin tercih ettikleri sağlık sistemi modeline göre ağırlığı değişmekle birlikte kamu ve özel sağlık sigortalarının entegre olarak kullanıldığı söylenebilir. Sistemin özel tamamlayıcı sağlık sigortası modeli ile desteklenerek kullanılabileceği ifade edilmiştir.

Alan (2009: 104-105) tarafından, Türkiye'de özel sağlık sigortacılığı sektörünün toplumdaki algısını ölçmeye yönelik yürütülen çalışmada, özel sağlık sigortasına sahip olan ve olmayan bireylerin algıları arasında fark olduğu değerlendirilmiştir. Bireylerin özel sağlık sigortalarını tercih etmelerinde, özel sağlık kuruluşlarından hizmet almayı kolaylaştırması en önemli faktör olarak gösterilmiştir. Benzer şekilde Orhaner ve Ekinci (2019: 34) tarafından, bireylerin özel sağlık sigortacılığına bakış açılarının değerlendirilmesi amacıyla yapılan çalışmada, demografik değişkenlerin bireylerin bakış açıları üzerinde etkili olduğu, önemli bir bölümünün daha önce tamamlayıcı sağlık sigortası kavramını duymadığı ve yaptırmayı düşünmediği ifade edilmiştir. Özel sağlık sigortası yaptırmamanın sebepleri arasında; ihtiyaç duymama, yeterli bilgiye sahip olunmaması, ekonomik sebepler ve sosyal güvenlik sigortası 
kapsamında olma gösterilmiştir. Yayar ve Daşçı (2020: 34) tarafından bireylerin özel sağlık sigortası tercihini etkileyen faktörlerin incelenmesine yönelik yapılan çalışmada, bireylerde bir hastalığın var olması, hekim uyarılarını dikkate alma ve gelir durumu ile eğitim düzeyi değişkenlerinin, özel sağlık sigortası kullanım tercihini pozitif yönde etkilediği sonucuna ulaşılmıştır. Bunun yanında sağlıklı beslenme çabası ve yaş değişkenleri negatif yönde etkilemektedir. Tarım ve Güdük (2019: 196) tarafından bireylerin özel sağlık sigortası yaptırma ve yaptırmama sebeplerini belirlemek amacıyla yaptıkları çalışmada; özel sağlık sigortası bulunan bireylerin \%59,54'ü "daha kaliteli hizmet almak" amaciyla sigorta yaptırdığını belirtmiştir. Özel sağlık sigortası yaptırmayan bireylerin en önemli gerekçesi ise \%53,81 oranı ile "primlerin çok yüksek olması" olarak belirtilmiştir.

\section{II- YÖNTEM}

Çalışmanın amacı, Türkiye'de özel sağlık sigortacılığının SWOT analizi vasıtasıyla mevcut durumunun analiz edilmesidir. Belirlenen amaca ulaşabilmek için Delphi yönteminden faydalanılmıştır. Karma bir yöntem olan Delphi yöntemi, verilerin uzman görüşü alınarak elde edilmesi sebebiyle nitel bir araştırma yönteminin özelliklerini taşırken, elde edilen verilerin değerlendirilmesi aşamasında nicel bir araştırma yöntemi özellikleri taşımaktadır. Bu özellikleri Delphi yöntemini karma bir araştırma yöntemi yapmaktadır (Stewart, 2001: 922).

Çalışma; problemin belirlenmesi, uzman grubun belirlenmesi, taslak analizin oluşturulması, ilk tur değerlendirmelerin yapılması, ikinci tur değerlendirmelerin yapılması ve üzerinde uzlaşı sağlanan ifadelerin kabul edilmesi olmak üzere altı aşamada yürütülmüştür (Şekil 1).

Şekil 1. Delphi Yöntemi Uygulanma Aşamaları

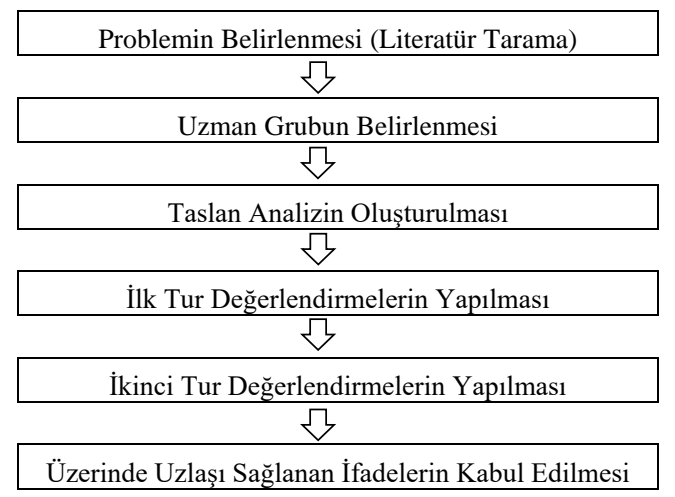

Kaynak: (Araştırmacılar tarafından oluşturulmuştur)

Problemin belirlenmesi aşamasında, yapılan literatür taraması sonucunda özel sağlık sigortacılığının Türkiye'deki mevcut durumunu analiz eden bir çalışmaya rastlanmamıştır. Bu araştırmada, Türkiye'de özel sağlık sigortacılığı için; "fırsatlar, tehditler, zayıf ve güçlü yönler" in belirlenmesi için aşağıdaki araştırma sorularına yanıtları bulunmaya çalışılmıştır.

1. Türkiye'de özel sağlık sigortacılığg için güçlü yönler nelerdir?

2. Türkiye'de özel sağlı sigortacılığı için zayıf yönler nelerdir?

3. Türkiye'de özel sağlık sigortacılığı için firsatlar nelerdir?

4. Türkiye'de özel sağlık sigortacılığı için tehditler nelerdir? 
Uzman grubun belirlenmesi aşamasında, konu ile ilgili yayınları bulunan ve çalışmaya katılmayı kabul eden 10 akademisyen uzman grubuna dâhil edilmiştir. Literatürde yöntemin uygulanması için en az 7 kişilik bir uzman grubu önerilmekle birlikte, bu sayının 10-20 arasında olması tavsiye edilmektedir (Şahin, 2001: 217).

Taslak analizin oluşturulması aşamasında, yapılan literatür taraması ile belirlenen ifadeler kullanılarak taslak SWOT analizi oluşturulmuştur. İlk tur değerlendirme kapsamında, oluşturulan taslak analiz formu uzman gruba e-posta yoluyla gönderilmiştir. Oluşturulan ifadelere dair uzmanlar tarafından yapılan değerlendirme sonuçları toplanmış ve yapılan eleştirilere göre form üzerinde düzenlemeler yapılmıştır. Bu kapsamda bazı yeni ifadeler eklenirken, bazı ifadeler çıkarılmış ya da daha anlaşılır olması açısından düzenlenmiştir. Daha sonra 7'li likert ölçeğinde hazırlanan maddelerden oluşan anket uzmanlar tarafından cevaplanmış ve grup kararına ulaşılmıştır $\mathrm{Bu}$ aşamada nicel veri analizi yöntemleri kullanılmaktadır. Şahin (2001: 218); Yurt ve Kadıŏlu (2019: 51) tarafindan, bu çalışmada olduğu gibi likert tipi bir ölçüm yapılmış ise; medyan (M), birinci çeyrek (Ç1), üçüncü çeyrek (Ç3) ve çeyrekler arası genişlik (G) ölçülerek maddeler üzerindeki uzlaşı durumunun kontrol edilmesi önerilmektedir.

İlk tur değerlendirme sonucunda elde edilen form gözden geçirilmiş ve yeniden düzenlenerek ikinci tur değerlendirme için uzman gruba tekrar gönderilmiştir. Bu aşamada her bir uzmana özel olarak oluşturulan formda, ilk tur sonrası yapılan düzenlemelerle birlikte, her bir ifade için ortak grup puanı ve ilgili uzmanın değerlendirme puanı bildirilmiştir. $\mathrm{Bu}$ aşamada uzmanlardan ilk turda olduğu gibi, ifadeler üzerinde düzenleme öneri varsa belirtmeleri istenmiştir. Ayrıca bu aşamada, grup ortalama puanı ile kendi puanlarını karşılaştırmaları ve uygun bulmaları halinde, kendi puanlarını uzlaşı kapsamında güncellemeleri talep edilmiştir. Elde edilen ikinci değerlendirme formları sonrasında formda yer alan ifadeler nihai hale kavuşmuş ve üzerinde uzlaşılan ifadeler kabul edilmiştir. Uzlaşılan maddelerin belirlenmesinde, Zeliff ve Heldenbrand tarafından önerildiği gibi çeyrekler arası genişliği 1,2'den az olma ölçütü kullanılmıştır (Aktaran: Şahin, 2001: 219). Kabul kriteri olarak ise, üzerinde uzlaşı sağlansa dahi, 7'li likert ölçeğinde ortalama puanı 5 'in altında kalan ifadeler nihai formdan çıkarılmıştır.

Çalışma için etik kurul izni, Afyon Kocatepe Üniversitesi Sosyal ve Beşeri Bilimleri Bilimsel Araştırma ve Yayın Etiği Kurulunun 27.07.2020 tarih ve 05 sayılı onayı ile alınmıştır.

\section{III- BULGULAR}

\section{A- İlk Tur Değerlendirme}

İlk tur değerlendirme kapsamında, literatür taraması yoluyla elde edilen SWOT analizine dair yarı yapılandırılmış taslak form oluşturulmuştur. Oluşturulan taslak formda; güçlü yönler için 6, zayıf yönler için 14, fırsatlar için 9 ve tehditler için 10 ifadeye yer verilmiştir. Form üzerinde yer alan yönergede ilgili bölüme dair eklenmesi ya da çıkartılması istenen ifadenin belirtilmesi ve tüm ifadelerin puanlanması istenmiştir.

Yapılan ilk tur değerlendirme sonucunda; güçlü yönlere 4, zayıf yönlere 5, firsatlara 1 ve tehditlere 2 yeni ifade önerilmiştir. Yapılan önerilerin tamamı, uzmanlarca ikinci turda değerlendirilmesi amacıyla forma eklenmiştir. Ayrıca bu aşamada her bir uzmana ait değerlendirme puanı birleştirilerek ortalama grup puanı elde edilmiştir. 


\section{B- İkinci Tur Değerlendirme}

İkinci tur değerlendirme kapsamında yeni eklenen ifadelerle birlikte, tüm ifadeler için grup ortalama puanı ve ilgili uzmanın bireysel puanının yer aldığı formlar, uzman grupta yer alan her bir uzmana bireysel olarak gönderilmiştir. Uzmanlardan eklenmesini ya da çıkartılmasını istedikleri ifadeler varsa belirtmeleri ayrıca yeni ifadeleri puanlamaları ve grup ortalama puanını da dikkate alarak uygun gördükleri durumda kendi puanlarını güncellemeleri istenmiştir. Bu aşamada yapılan değerlendirmeler sonucunda, tehditler bölümü ile ilgili bir ifade haricindeki yeni ifadelerin tamamı kabul edilmiştir.

\section{C- Nihai Değerlendirme}

Yapılan nihai değerlendirme kapsamında; SWOT analizini oluşturan maddelere dair ortalama, birinci çeyrek (Ç1), medyan (M), üçüncü çeyrek (Ç3) ve çeyrekler arası genişlik (G) belirlenmiştir. Çeyrekler arası genişliği 1,2 ve daha büyük olan maddeler, üzerinde uzlaşı sağlanamayan ifadeleri oluştururken, ortalama puanı 5'in altında olan maddeler kabul kriterini sağlayamayan ifadeleri oluşturmaktadır. Türkiye'de özel sağlık sigortacılığının mevcut durum analizi kapsamında oluşturulan SWOT analizinde toplam 50 ifadeye yer verilmiştir. Bu ifadelerden 39 tanesi kabul kriteri olan 5 ve üzeri ortalama puan almış ve üzerlerinde uzlaşı sağlanmıştır. Geriye kalan 11 ifadenin 6 tanesi kabul kriterini sağlayamamış ve aynı zamanda bunlar arasında 10 kriter üzerinde uzlaşı da sağlanamamıştır.

Tablo 2'de Türkiye'nin özel sağlık sigortacılığı açısından güçlü yönlerine dair yer alan G4, G6 ve G8 ifadeleri üzerinde uzlaşı sağlanamadığı için formdan çıkartılmıştır $(G \geq 1,2)$. Ayrıca kabul kriterini sağlayamayan G4 ve G8 ifadeleri bu aşamada nihai formdan çıkarılmıştır (Ort. $<5)$. Geriye kalan 7 ifade üzerinde uzlaşı sağlanarak kabul edilmiştir $(\mathrm{G}<1,2)$.

Tablo 2. Türkiye'nin Özel Sağllk Sigortacılı̆̆ı Açısından Güçlü Yönleri

\begin{tabular}{|c|c|c|c|c|c|}
\hline Güçlü Yönler & Ort. & Ç1 & $\mathbf{M}$ & Ç3 & G \\
\hline G1-Özel sağlık sigortalarında kişiye özel poliçelerin oluşturulabilmesi & 5,40 & 5 & 5,5 & 6 & 1 \\
\hline G2-Yasal düzenlemelerin yeterli olması & 5,40 & 5 & 5,5 & 6 & 1 \\
\hline G3-Özel sağlık sigortalarının belirli standartlara sahip olması & 5,70 & 5 & 6 & 6 & 1 \\
\hline G4-Türkiye'nin sağlık sigortacılığı konusunda tecrübe sahibi olması & 4,80 & 3,5 & 5 & 6 & 2,5 \\
\hline $\begin{array}{l}\text { G5-Sağlık sigortacılığı alanında çalışan personelin uzmanlık seviyesinin yüksek } \\
\text { olması }\end{array}$ & 5,60 & 5 & 6 & 6 & 1 \\
\hline G6-Türkiye'de reasürans şirketlerinin bulunması & 5,50 & 4,5 & 5,5 & 6,5 & 2 \\
\hline $\begin{array}{l}\text { G7-Tamamlayıcı sağlık sigortası ve zorunlu mali sorumluluk sigortaları ile } \\
\text { sektörün genişleme potansiyelinin olması }\end{array}$ & 5,50 & 5 & 5,5 & 6 & 1 \\
\hline $\begin{array}{l}\text { G8-Hem sağlık sigortası ve hem de sağlık hizmetleri sunumunu bir şirket altında } \\
\text { veren kurumların bulunması }\end{array}$ & 4,10 & 3,5 & 4 & 5 & 1,5 \\
\hline $\begin{array}{l}\text { G9-Tamamlayıcı sağlık sigortası türü ile SGK mensubu sigortalıların düşük } \\
\text { düzeyde prim ödemesi }\end{array}$ & 5,40 & 5 & 5 & 6 & 1 \\
\hline $\begin{array}{l}\text { G10-Özel sağlık sigortasının daha kaliteli hizmet sunumu sağlaması ve bekleme } \\
\text { süresinin oldukça düşük olması }\end{array}$ & 5,80 & 5 & 6 & 6 & 1 \\
\hline
\end{tabular}


Tablo 3'te Türkiye'nin özel sağlık sigortacılığı açısından zayıf yönlerine dair yer alan Z5, Z8, Z12, Z13, Z15 ve Z19 ifadeleri üzerinde uzlaşı sağlanamadığı için formdan çıkartılmıştır $(G \geq 1,2)$. Ayrıca kabul kriterini sağlayamayan $Z 12, Z 13$ ve $Z 19$ ifadeleri bu aşamada nihai formdan çıkarılmıştır (Ort.<5). Geriye kalan 13 ifade üzerinde uzlaşı sağlanarak kabul edilmiştir $(\mathrm{G}<1,2)$.

Tablo 3. Türkiye’nin Özel Sağllk Sigortacılığı Açısından Zayıf Yönleri

\begin{tabular}{|c|c|c|c|c|c|}
\hline Zayıf Yönler & Ort. & Ç1 & $\mathbf{M}$ & Ç3 & G \\
\hline Z1-Maddi imkânı ÖSS primi ödemeye yeterli kişi sayısının az olması & 5,50 & 5 & 6 & 6 & 1 \\
\hline Z2-Tanıtım eksikliği & 5,60 & 5 & 5,5 & 6 & 1 \\
\hline Z3-Pazarlama eksikliği & 5,30 & 5 & 5 & 6 & 1 \\
\hline Z4-Devlet desteğinin olmaması & 5,40 & 5 & 6 & 6 & 1 \\
\hline Z5-Sigorta acentelerinde çalışan bireylerin ÖSS konusundaki bilgi yetersizliği & 5,00 & 4,5 & 5 & 6 & 1,5 \\
\hline Z6-Müşterilerin ÖSS hakkında yeterli düzeyde bilgiye sahip olmamaları & 6,20 & 6 & 6 & 7 & 1 \\
\hline Z7-ÖSS maliyetlerinin yüksek olması & 5,90 & 5,5 & 6 & 6 & 0,5 \\
\hline Z8-Türkiye'de reasürans şirket sayısının az olması & 5,30 & 4,5 & 5,5 & 6 & 1,5 \\
\hline Z9-ÖSS fiyatını belirlemenin zor olması & 5,30 & 5 & 5 & 6 & 1 \\
\hline Z10-Türkiye'de ÖSS sektörünün küçük olması & 5,70 & 5 & 6 & 6 & 1 \\
\hline Z11-Özel sağlık sigortasına talebin az olması & 5,90 & 6 & 6 & 6 & 0 \\
\hline $\begin{array}{l}\text { Z12-Riske sebep olan durumun sigorta süresi içinde gerçekleşip } \\
\text { gerçekleşmediğinin bilinememesi }\end{array}$ & 4,80 & 4 & 5 & 5,5 & 1,5 \\
\hline Z13-Fiyatların bireyin özelliklerine (hastalık, yaş) göre değişmesi & 4,90 & 4 & 5 & 6 & 2 \\
\hline Z14-Sigorta süresinin kısa olması & 5,30 & 5 & 5 & 6 & 1 \\
\hline $\begin{array}{l}\text { Z15-Ülkemizde tarihsel olarak sağlık hizmetleri sunum ve finansmanının kamu } \\
\text { sektörünce karşılanması anlayışının var olması }\end{array}$ & 5,20 & 4 & 5,5 & 6 & 2 \\
\hline Z16-Hane halkı gelir düzeyinin düşük olması & 5,80 & 5 & 6 & 6 & 1 \\
\hline Z17-Toplumun sigorta konusundaki bilgi ve bilinç düzeyinin düşük olması & 5,70 & 5 & 6 & 6 & 1 \\
\hline Z18-Her sağlık riski için ayrı prim ödenmesi & 5,60 & 5 & 6 & 6 & 1 \\
\hline $\begin{array}{l}\text { Z19-Özel sağlık sigortalarının, sigortalının bakmakla yükümlü olduğu kişileri } \\
\text { kapsamaması }\end{array}$ & 4,10 & 3,5 & 4 & 5 & 1,5 \\
\hline
\end{tabular}

Tablo 4'te Türkiye'nin özel sağlık sigortacılı̆̆ açısından fırsatlarına dair yer alan F1 ifadesi üzerinde uzlaşı sağlanamadığı için formdan çıkarılmıştır $(G \geq 1,2)$. Geriye kalan 9 ifade üzerinde uzlaşı sağlanarak kabul edilmiştir $(G<1,2)$. 
Sosyal Güvenlik Dergisi • Journal of Social Security • 2021/1

Tablo 4. Türkiye 'nin Özel Sağlık Sigortacılığı Açısından Fırsatları

\begin{tabular}{|c|c|c|c|c|c|}
\hline Fursatlar & Ort. & Ç1 & $\mathbf{M}$ & Ç3 & G \\
\hline F1-Türkiye'nin ekonomik açıdan büyüyen bir ülke olması & 5,00 & 4 & 5 & 6 & 2 \\
\hline F2-Yaşlı nüfus oranının artması & 5,20 & 5 & 5 & 6 & 1 \\
\hline F3-İnsanların sağlığına daha fazla önem vermeleri & 5,90 & 6 & 6 & 6 & 0 \\
\hline F4-Kronik hastalıkların artma eğiliminde olması & 5,50 & 5 & 6 & 6 & 1 \\
\hline F5-Akredite olmuş özel sağlık kuruluşu sayısının fazla olması & 5,60 & 5 & 6 & 6 & 1 \\
\hline F6-Türkiye'de özel sağlık sigortacılığı sektörünün büyümeye açık olması & 5,90 & 5,5 & 6 & 6 & 0,5 \\
\hline F7-GSS’nin özel hastane giderlerinin tamamını karşılamaması & 5,80 & 5,5 & 6 & 6 & 0,5 \\
\hline $\begin{array}{l}\text { F8-Sigortacılık konusunda eğitim veren (uzman personel yetiştiren) kurum } \\
\text { sayısının artıyor olması }\end{array}$ & 5,90 & 6 & 6 & 6 & 0 \\
\hline F9-Türkiye'de sağlık hizmetlerine talebin fazla olması & 5,70 & 5 & 6 & 6 & 1 \\
\hline $\begin{array}{l}\text { F10-Salgın vb. durumlarda insanların, daha az yoğun olması ve tele-tıp gibi } \\
\text { uygulamaların bulunması nedeniyle özel sağlık kuruluşu tercihlerinin artması }\end{array}$ & 5,60 & 5 & 6 & 6 & 1 \\
\hline
\end{tabular}

Tablo 5'te Türkiye'nin özel sağlık sigortacılığı açısından tehditlerine dair yer alan T1 ifadesi üzerinde uzlaşı sağlanamadığı $(G \geq 1,2)$ ve aynı zamanda kabul kriterini sağlayamadığı $($ Ort. $<5)$ için bu aşamada nihai formdan çıkarılmıştır. Geriye kalan 10 ifade üzerinde uzlaşı sağlanarak kabul edilmiştir $(G<1,2)$.

Tablo 5. Türkiye'nin Özel Sağlık Sigortacıllğı Açısından Tehditleri

\begin{tabular}{|c|c|c|c|c|c|}
\hline Tehditler & Ort. & Ç1 & $\mathbf{M}$ & Ç3 & G \\
\hline T1-Talebe göre sağlık sigortası şirketlerinin sayıca fazla olması & 4,50 & 4 & 4 & 5,5 & 1,5 \\
\hline T2-Toplumun tamamına yakınının GSS kapsamında olmas1 & 5,60 & 5 & 5,5 & 6 & 1 \\
\hline $\begin{array}{l}\text { T3-Kamu hastanelerinde yatarak verilen sağlık hizmetlerinin tamamına } \\
\text { yakınının GSS kapsamında olması }\end{array}$ & 6,10 & 6 & 6 & 6 & 0 \\
\hline $\begin{array}{l}\text { T4-Kamu hastanelerinde ayaktan verilen sağlık hizmetlerinin tamamına } \\
\text { yakınının GSS kapsamında olması }\end{array}$ & 5,90 & 6 & 6 & 6 & 0 \\
\hline T5-İlaç giderlerinin tamamına yakınının GSS kapsamında olması & 5,60 & 5 & 6 & 6 & 1 \\
\hline T6-Rakiplerin fazla olması & 5,30 & 5 & 5 & 6 & 1 \\
\hline T7-Rakiplerin güçlü olması & 5,20 & 5 & 5 & 6 & 1 \\
\hline T8-Riskin değişken olması & 5,40 & 5 & 5,5 & 6 & 1 \\
\hline $\begin{array}{l}\text { T9-ÖSS primi ödeyen ve çalışan bireylerin aynı zamanda sosyal güvelik primi } \\
\text { ödemesi }\end{array}$ & 5,80 & 5,5 & 6 & 6 & 0,5 \\
\hline T10-Ekonomik istikrarsızlık ve yüksek işsizlik oranı & 6,00 & 5,5 & 6 & 6,5 & 1 \\
\hline T11-ÖSS sisteminin sağlık giderlerinin \%100'nü karş1lamaması (sınırlama olması) & 6,10 & 6 & 6 & 6,5 & 0,5 \\
\hline
\end{tabular}


Türkiye'de özel sağlık sigortacılığının mevcut durum analizi kapsamında; zayıf yönlere dair "Z11-Özel sağlık sigortasına talebin az olması" ifadesi, firsatlara dair "F3-İnsanların sağlığına daha fazla önem vermeleri" ve "F8-Sigortacılık konusunda eğitim veren (uzman personel yetiştiren) kurum sayısının artıyor olması" ifadeleri ile tehditlere dair "T3-Kamu hastanelerinde yatarak verilen sağlık hizmetlerinin tamamına yakınının GSS kapsamında olması "ve "T4-Kamu hastanelerinde ayaktan verilen sağlık hizmetlerinin tamamına yakınının GSS kapsamında olması" ifadeleri üzerinde uzlaşının tam olduğu $(\mathrm{G}=0)$ ifadelerdir. $\mathrm{Bu}$ ifadeler uygulanan yöntemin amacına uygun olacak şekilde tüm uzmanlarca üzerinde uzlaşının sağlanması açısından önemlidir. Ayrıca, Türkiye'de özel sağlık sigortacılığının mevcut durum analizi kapsamında zayıf yönler içerisinde ele alınan "Z6Müşterilerin ÖSS hakkında yeterli düzeyde bilgiye sahip olmamaları" ifadesi en yüksek ortalama puan ile üzerinde uzlaşı sağlanan ifade olmuştur.

\section{IV-TARTIŞMA}

Ülkelerin uyguladığı sağlık politikaları, o ülkede özel sağlık sigortası sektörünün gelişimini doğrudan etkilemekte ve bu etkinin yönünü de belirlemektedir. Her ne kadar gelişmiş ülkelerin gerisinde kalmış olsa da Türkiye'de özel sağlık sigortasının son dönemde artma eğiliminde olması, özel sektörün hizmet sunumundaki artan payı ile açıklanabilir.

Tatar (2011: 111) tarafindan sağlık hizmetlerinin finansman modelleri ile ilgili olarak sosyal sağlık sigortası modelinin Türkiye'deki gelişiminin incelendiği bir çalışma yürütülmüştür. Yapılan çalışmada, sosyal sigorta ile özel sağlı sigortası modellerine dair bazı temel çıkarımlarda bulunulmuştur. En belirgin fark olarak; sosyal sigorta modelinde bireylerin riskleri ve sağlik statüleriyle, ödenecek primler arasında herhangi bir ilişkinin olmamasına karşın, özel sağlık sigortası modelinde bireylerin sağlık statülerinin düşmesi ve risklerin artmasının, ödenecek primleri de artırdığı ifade edilmiştir. Yapılan bu çalışmada sektörün belirli standartlara sahip olması, yasal mevzuatının yeterli olması ve sektörün tamamlayıcı sağlık sigortaları aracılı̆̆ıyla genişleme potansiyelinin olması, güçlü yönler arasında gösterilmiş ve bu maddeler üzerinde uzlaşı sağlanmıştır.

Orhaner (2017: 411) tarafından Türkiye'de özel sağlık sigortacılığı sisteminin gelişmesi için yapılabilecek düzenlemelerin incelendiği çalışmada, nüfusun artması, bireylerin sağlık duyarlılıklarının artması, kişi başı gelirin artması ve yapılabilecek bazı düzenlemelerle özel sağlık sigortalarına olan talebin artabileceği ifade edilmiştir. Bu talebin artması için sektörün indirim ve muafiyet gibi bazı özendirici uygulamalar yapması önerilmektedir. Ancak yapılan çalışmada nüfusun artmasının yanında, özel sağlık sigortası primi ödeyebilecek maddi olanaklara sahip kişi sayısının az ve hane halkı gelir düzeyinin düşük olması, maliyetlerin yüksek olması dolayısıyla talebin az olması önemli zayıflıklar olarak ortaya koyulmuştur. Ayrıca Orhaner (2017: 411) tarafından önerilen talep artırıcı düzenlemelerle ilgili olarak, yasal düzenlemelerin yapılmış olması ve bu kapsamda tamamlayıcı sağlık sigortası gibi uygulamaların bulunması geçen süreçte bu konuda olumlu gelişmelerin olduğunun göstergesi olarak değerlendirilebilir.

Özsarı ve Güdük (2020: 527) tarafından, özel sağlık sigortacılığının mevcut durumu, sorunları, gelişimi için neler yapılabileceği ve sektörü gelecekte nelerin beklediğine dair bir çalışma yapılmıştır. Çalışma sonucunda, sektörün gelişmiş ülkelere oranla daha az geliştiği ve bu durumun ortaya çıkmasının Türkiye'nin uyguladığı politikaların bir sonucu olduğu belirtilmiştir. Bu çerçevede; sağlık hizmetlerinin sosyal devlet anlayışıyla değerlendirilerek, kamu tarafından geniş kapsamlı olarak sunulmasının yanında, bireylerin kamu sağlık tesislerinde sunulan hizmetten genel olarak memnun olması ve erişimde sorun yaşanmaması önemli etkenler olarak gösterilmiştir. Yapılan bu çalışmada da benzer sonuçlara ulaşılmış 
olup, toplumun tamamına yakınının GSS kapsamında olması, sektör açısından bir tehdit olarak üzerinde uzlaşılan konulardan birini oluşturmaktadır. Ayrıca Özsarı ve Güdük (2020: 527) tarafından, özel sağlık sigortası tercihinin üst gelir grupları ile sınırlı kaldığı ve lüks bir tercih olarak görüldüğü ifade edilmiştir. Yapılan bu çalışmada da benzer şekilde, hane halkı gelir düzeyinin düşük olması durumu sektör açısından önemli bir zayıflık olarak ifade edilmiş ve çalışma sonuçları bu açılardan da benzerlik göstermiştir.

Tapan, Alıcı, Yıldırım ve Gayef (2015: 85) tarafından tamamlayıcı sağlık sigortası tercihlerinin incelendiği bir çalışma yürütülmüştür. Özel sağlık sigortası temsilcileri ile yapılan çalışmada, katılımcıların \%93'ü tamamlayıcı sağlık sigortasını, genel sağlık sigortasının sürdürülebilirliği açısından önemli ve birlikte kullanılmasının sektörün geleceği açısından gerekli olduğu sonucuna ulaşılmıştır. Benzer şekilde, Özer (2015: 167) tarafindan sektör temsilcileri ile yapılan bir çalışmada, katılımcıların \%37,35'inin özel sağlık sigortası türlerinden biri olan tamamlayıcı sağlık sigortasına olumlu bir gelişme olarak yaklaştıkları ve sektörün finansal sürdürülebilirliğine katkı sunabileceği sonucuna ulaşmıştır. Balkanlı (2017: 62) tarafından, Türkiye ve dünyada özel sağlık sigortacılığının incelenmesine yönelik yapılan çalışmada, özel sağlık sigortasının tamamlayıcı olarak genel sağlık sistemine entegre edilmesinin daha uygun bir yöntem olduğu belirtilmiştir. Bu kapsamda da genellikle ülkelerin tercih ettikleri sağlı sistemi modeline göre ağırlığ 1 değişmekle birlikte kamu ve özel sağlık sigortalarının entegre olarak kullanıldığı söylenebilir. Sistemin özel tamamlayıcı sağlık sigortası modeli ile desteklenerek kullanılabileceği ifade edilmiştir. Yapılan bu çalışmada da benzer şekilde, tamamlayıcı sağlı sigortasının, sektörün gelişimi açısından önemli bir potansiyel barındırdığı ve SGK mensuplarına düşük primlerle sigorta yapabilme avantajı sağlamış olması güçlü yönler arasında gösterilmiştir.

Alan (2009: 104-105) tarafından, Türkiye'de özel sağlık sigortacılığı sektörünün toplumdaki algısını ölçmeye yönelik yürütülen çalışmada, özel sağlık sigortasına sahip olan ve olmayan bireylerin sektöre dair algıları arasında fark olduğu değerlendirilmiştir. Bireylerin özel sağlık sigortalarını tercih etmelerinde, özel sağlık kuruluşlarından hizmet almayı kolaylaştırması en önemli faktör olarak gösterilmiştir. Yapılan bu çalışmada da özel sağlık sigortasının daha kaliteli hizmet sunumu sağlaması ve bekleme süresinin oldukça düşük olması önemli bir güçlü yön olarak ifade edilmiştir.

Orhaner ve Ekinci (2019: 34) tarafından, bireylerin özel sağlık sigortacılığına bakış açılarının değerlendirilmesi amacıyla yapılan çalışmada, demografik değişkenlerin bireylerin bakış açıları üzerinde etkili olduğu, önemli bir bölümünün daha önce tamamlayıcı sağlık sigortası kavramını duymadığı ve yaptırmayı düşünmediği ifade edilmiştir. Bu çalışmada da "Müşterilerin ÖSS hakkında yeterli düzeyde bilgiye sahip olmamaları" en zayıf yönlerden biri olarak tespit edilmiştir. Toplumun özel sağlık sigortacılığ bilgilendirilmesinin özel sağlık sigortacılığına talebi arttırabileceği düşünülmektedir. Ayrıca Orhaner ve Ekinci (2019: 34), özel sağlı sigortası yaptırmamanın sebepleri arasında; ihtiyaç duymama, yeterli bilgiye sahip olunmaması, ekonomik sebepler ve GSS kapsamında olma gösterilmiştir. Yapılan bu çalışmada da toplumun tamamına yakınının GSS kapsamında olması sektör açısından bir tehdit olarak karşılanırken, GSS'nin özel hastane giderlerini (bir bölümünü ya da tamamını) karşılamaması bir fırsat olarak değerlendirilmiştir.

Yayar ve Daşçı (2020: 34) tarafından bireylerin özel sağlık sigortası tercihini etkileyen faktörlerin incelenmesine yönelik yapılan çalışmada, bireylerde bir hastalığın var olması, hekim uyarılarını dikkate alma ve gelir durumu ile eğitim düzeyi değişkenlerinin, özel sağlık sigortası kullanım tercihini pozitif yönde etkilediği sonucuna ulaşılmıştır. Bunun yanında sağlıklı beslenme çabası ve yaş değişkenleri negatif yönde etkilemektedir. Yapılan bu çalışmada da benzer şekilde, maddi olanakları ÖSS primi ödemeye yeterli kişi sayısının az 
Türkiye'de Özel Sağlık Sigortacılı̆̆g Sisteminin Mevcut Durum Analizi

olması sektörün zayıf yönleri arasında gösterilmiştir. Tarım ve Güdük (2019: 196) tarafından bireylerin özel sağlık sigortası yaptırma ve yaptırmama sebeplerini belirlemek amaciyla yapılan çalışmada; özel sağlı sigortası bulunan bireylerin \%59,54'ü "daha kaliteli hizmet almak" amacıyla sigorta yaptırdığını belirtmiştir. Özel sağlık sigortası yaptırmayan bireylerin en önemli gerekçesi ise \%53,81 oranı ile "primlerin çok yüksek olması" olarak belirtilmiștir. Yapılan bu çalışmada da benzer şekilde, özel sağlık sigortasının daha kaliteli hizmet sunumu sağlaması ve bekleme süresinin oldukça düşük olması sektör açısından önemli bir güçlü yön olarak gösterilmiştir. Aynı şekilde ÖSS maliyetlerinin yüksek olması da önemli bir zayıflık olarak gösterilmiştir.

\section{SONUÇ}

Sağlık hizmetlerinin finansmanının nasıl yapıldığı ve finansman yükünün paylaşım şekli, verilen hizmetin miktar, kalite, erişim ve hakkaniyet açısından etkilemekte dahası belirleyici olmaktadır. En önemli finansman yöntemlerinden biri olarak gösterilen özel sağlık sigortası ülkemizde gelişmiş ülkelere oranla oldukça geridedir. Bu durum Türkiye'nin sosyal bir sağlık politikası izlemesi ile açıklanabilir.

Temelde bireyler sağlıklarını korumak istemekle birlikte, her zaman bu mümkün olmamakta ve bozulan sağlığın geri kazanımı önemli bir istek durumuna gelmektedir. Ülke sağlık politikaları ve dolayısıyla oluşturulan sağlık sistemleri tüm bu aşamalarda ihtiyacı olan bireylere gerekli hizmeti sunmaya yöneliktir. Sağlık sistemleri uygulanan ağırlıklı finansman modeline göre adlandırılmaktadır. Türkiye sosyal güvenlik sistemi temelli bir sağlık sistemi kullanmaktadır. Türkiye'de ikamet eden herkes 2012 yılından itibaren zorunlu genel sağlık sigortası kapsamına alınmıștır. Ancak sosyal güvenlik sigortası her bir bireyin beklentisini karşılamayabilmektedir. Bazı durumlarda ise farklı nedenlerden dolayı özel hastanelerden hizmet almak isteyen bireyler olabilmektedir. Bu durum bireyleri özel sağlık sigortalarına yöneltmektedir.

Özel sağlık sigortası sistemi ülkemiz için birincil finansman aracı olarak kullanılmamasına ve geniş bir katılıma sahip olmamasıyla birlikte önemli kazanımları bulunmaktadır. Yeterli yasal düzenlemeler, bu alanda yetişmiş insan kaynağının bulunması ve tamamlayıcı sağlık sigortası sisteminin uygulanabilmesi bu açıdan önemli güçlü yanlar olarak sayılabilmektedir. Tüketicilerin ÖSS hakkında yeterli düzeyde bilgiye sahip olunmaması, maliyetlerin yüksek, talebin az ve hane halkı gelir düzeyinin düşük olması önemli zayıflıklar olarak sayılabilir. Nüfusun yaşlanması, kronik hastalıkların artması, kaliteli özel sağlık kuruluşlarının varlığ ve tercih edilmesi özel sağlık sigortacılığı açısından fırsat olarak değerlendirilebilir. GSS'nin önemli bir kapsayıcılığının bulunması, rakipler ve ekonomik durum önemli tehditler olarak siralanabilir.

Yapılan mevcut durum analizi ile elde edilen sonuçların incelenerek, güçlü yönlerin korunması, zayıflıkların geliştirilmesi, fırsatların değerlendirilmesi ve tehditlerin bertaraf edilmesine yönelik stratejiler geliştirilebilir. Yine bu stratejiler kapsamında; güçlü yönlerin firsatlardan yararlanacak şekilde kullanılması, zayıflıkların belirlenerek güçlü yönlere dönüştürülecek stratejilerin geliştirilmesi ve tehditlerin güçlü yanlarla birleştirilerek firsata dönüştürülmesine yönelik çalışmalar yapılabilir. Çalışma sonuçları bu konuda politika yapıcılara ve araştırmacılara fikir verebilir. Çalışma, konu ile ilgili akademik yayınları bulunan akademisyenler üzerinde yürütülmüş̧ür. Yapılacak ileriki çalışmalarda; SGK, Çalışma ve Sosyal Güvenlik Bakanlığı gibi sektörün diğer önemli paydaşlarından uzmanların katılımıyla tekrarlanarak sonuçlar karşılaştırılabilir. Ayrıca yapılacak çalışmalarda stratejik durum analizi için farklı yöntemler kullanılarak literatüre katkı sağlanabilir. 


\section{Kaynakça}

Ajmera, P. (2017). Ranking the Strategies for Indian Medical Tourism Sector Through the Integration of SWOT Analysis and TOPSIS Method. International Journal of Health Care Quality Assurance. 30(8). 668-679. [https:// doi.org/10.1108/IJHCQA05-2016-0073].

Alan, M. (2009). Özel Sağllk Sigortasinın Mevcut ve Potansiyel Müsteriler Tarafindan Algılanışı. Yüksek Lisans Tezi. Doğuş Üniversitesi.

Arora, S., Charlesworth, A., Kelly, E. ve Stoye, G. (2013). Public Payment and Private Provision: The Changing Landscape of Health Care in the 2000s. In Nuffield Trust. (Issue May). [https://www.nuffieldtrust.org.uk/files/2017-01/ public-payment-and-private-provisi on-webfinal.pdf]. (Erişim: 02 Aralık 2020).

Ateş, M. (2011). Sağlık Sistemleri. İstanbul: Beta Yayıncilik.

Balkanlı, M. (2017). Özel Sağlık Sigortasl Türkiye ve Dünya Uygulamalart. Yüksek Lisans Tezi. Başkent Üniversitesi.

Brown, B. B. (1968). Delphi Process: A Methodology Used for the Elicitation of Opinions of Experts. In ASTME Vectors .Issue February. 1-15.

Çoban, B. ve Karakaya, Y. E. (2010). Geleceği Planlamada Stratejik Yönetim ve SWOT Analizi: Kavramsal Yaklaşımlar. New World Sciences Academy. 5(4). 342-352.

Dalkey, N. ve Helmer, O. (1962). An Experimental Application of the Delphi Method to the Use of Experts. The RAND Corporation. Santa Monica.

Deloitte (2015). Tamamlayıcı Özel Sağlık Sigortası Dünya Uygulamalarından Örneklerin Incelenmesi ve Türkiye için Öneriler Raporu. [https://www.tsb.org.tr/Document/Yonetmelikl er/20151023-Tamamlayıc1_Sağlık_Sigortas1Final(1).pdf]. (Erişim: 05 Aralık 2020).

Erffmeyer, R. C., Erffmeyer, E. S. \& Lane, I. M. (1986). The Delphi Technique: An Empirical Evaluation of the Optimal Number of Rounds. Group ve Organization Management. 11(1-2). 120-128. [https://doi.org/10.1177/10596011860 1100110].
Ervural, B. C., Zaim, S., Demirel, O. F., Aydın, Z. ve Delen, D. (2018). An ANP and Fuzzy TOPSIS-Based SWOT Analysis for Turkey's Energy Planning. In Renewable and Sustainable Energy Reviews. 82 June. 1538-1550. [https://doi.org/10.1016/j.rser.2017.06.095].

Gordon, T. J. (1994). The Delphi Method. Futures Research Methodology. [http://www. gerenciamento.ufba.br/downloads/delphi_meth od.pdf]. (Erişim: 01 Aralık 2020).

Gürel, E. ve Tat, M. (2017). SWOT Analysis: A Theoretical Review. Uluslararası Sosyal Araştırmalar Dergisi. 10(51). 13-14.

Helms, M. M. ve Nixon, J. (2010). Exploring SWOT Analysis - Where are We Now? A Review of Academic Research From the Last Decade. In Journal of Strategy and Management. 3(3). [https://doi.org/10.1108/ 17554251011064837].

Hill, T. ve Westbrook, R. (1997). SWOT Analysis: It's Time for a Product Recall. Long Range Planning. 30(1). 46-52. [https://doi.org/10.1016/S0024-6301(96)00095-7].

Jenkins, D. A. ve Smith, T. E. (1994). Applying Delphi Methodology in Family Therapy Research. Contemporary Family Therapy. 16(5). 411-430. [https://doi.org/10.1007/BF 02197902].

Kamilçelebi, H. (2012). Türkiye'de Sigorta Sektörünün SWOT Analizi ve Bir Araştırma. Ekonomi Bilimleri Dergisi. 4(1). 4554.

Karakök, T. (2011). Zonguldak Kömür Havzasında Bir Yardım Sandığı: Amele Birliği. ZKÜ Sosyal Bilimler Dergisi. 7(13). 351-367.

Koçkaya, G., Atikeler, K. ve Yenilmez, F. B. (2016). Türkiye Özel ve Kamu Sağlık Sigortacılı̆̆ Prim/Hasar Sağlı Harcaması Değerlendirmesi. Sosyal Güvence. 5(9). 82-101. [https://doi.org/10.21441/sguz.2016917923].

OECD (Organisation for Economic Cooperation and Development). (2004). Proposal for A Taxonomy of Health Insurance. OECD Study on Private Health Insurance. Issue June. $1-21$. 
Türkiye'de Özel Sağlık Sigortacılığı Sisteminin Mevcut Durum Analizi

Orhaner, E. (2017). Sağlık Harcamalarının Finansmanında Özel Sağlık Sigortalarının Rolü. Uluslararası Sağlık Yönetimi ve Stratejileri Araştırma Dergisi. 3(3). 398-412.

Orhaner, E. (2018). Türkiye'de Sağllk Sigortacılliğl. Ankara: Siyasal Kitabevi.

Orhaner, E. ve Ekinci, N. (2019). Ankara'da Yaşayan Kişilerin Özel Sağlık Sigortalarına İlişkin Görüşlerinin Değerlendirilmesi. Sağllk Akademisyenleri Dergisi. 6(1). 34-42.

Özer, Ö. (2015). Türkiye Sağllk Sisteminde Finansal Sürdürülebilirlik: Paydaş Görüsleri ve Değerlendirmeleri. Doktora Tezi. Hacettepe Üniversitesi.

Özsarı, H. ve Güdük, Ö. (2020). Bazı Sigorta Şirketi Yöneticilerinin Türkiye'de Özel Sağlık Sigortacılığ1 Üzerine Bir Değerlendirmesi. Acıbadem Üniversitesi Sağlik Bilimleri Dergisi. 11(3). 526-536. [https://doi.org/https://doi.org/ $10.31067 / 0.2020 .303]$.

Shahabi, R. S., Basiri, M. H., Kahag, M. R. ve Zonouzi, S. A. (2014). An ANP-SWOT Approach for Interdependency Analysis and Prioritizing the Iran's Steel Scrap Industry Strategies. Resources Policy. 42. 18-26. [https://doi.org/10.1016/j.resourpol.2014.07.001].

Stewart, J. (2001). Is the Delphi Technique a Qualitative Method? Medical Education. 35(10). 922-923. [https://doi.org/DOI: 10.1046/j.1365-2923.2001.01045.x].

Şahin, A. E. (2001). Eğitim Araştırmalarında Delphi Tekniği ve Kullanımı. Hacettepe Üniversitesi Eğitim Fakültesi Dergisi. 20(20). 215-220.

T.C. Cumhurbaşkanlı̆̆ı. (2019). Onbirinci Kalkinma Planı. [https://www.sbb.gov.tr/kalkınmaplanlari]. (Erişim: 15 Aralık 2020).

Tapan, B., Alıc1, S., Y1ldırım, N. ve Gayef, A. (2015). Evaluation of Private Health Insurance Companies' Views on the Need for a Complementary Health Insurance for the Sustainability of General Health Insurance. Istanbul Bilim University Florence Nightingale Journal of Medicine. 1(2). 77-86. [https:// doi.org/10.5606/fng.btd.2015.015].

Tarım, M. ve Güdük, Ö. (2019). Türkiye'de Bireylerin Özel Sağlık Sigortası Tercihini Etkileyen Nedenler ve Bilgi Düzeyleri. Sağllk Akademisyenleri Dergisi. 6(3). 196-200.
Tatar, M. (2011). Sağlik Hizmetlerinin Finansman Modelleri: Sosyal Sağlık Sigortasının Türkiye'de Gelişimi. Sosyal Güvenlik Dergisi. 1(1). 103-133.

Tunc, O. ve Mithat, K. (2015). Private Health Insurance in Europe and Turkey. Pressacademia. 2(3). 409-425. [https://doi.org/ 10.17261/pressacademia.2015312963].

Türkiye Sigorta Birliği (2018). 2018 Sektör Raporu. [//tsb.org.tr/media/attachments/2018_ Y\%C4\%B11\%C4\%B1_Sektor_Raporu_Turkce.pdf]. (Erişim: 25 Kasım 2020).

Türkiye Sigorta Birliği (2019). 2019 Sektör Raporu. [https://tsb.org.tr/media/attachments/ 2019_Y\%C4\%B11\%C4\%B1_Sektor_Raporu.p df]. (Erişim: 24 Kasım 2020).

Yayar, R. ve Daşçı, A. N. (2020). Özel Sağlık Sigortası Talebini Etkileyen Faktörlerin İkili Lojistik Regresyon Yöntemiyle Analizi (İstanbul Örneği). Sosyal Güvenlik Dergisi. 10(1). 19-40. [https://doi.org/10.32331/ sgd. 752099].

Yiğit, G. ve Seker, Ș. E. (2016). Bilgisayarlı Argüman Delphi Yöntemi Kullanılarak Türkiye'de Nükleer Enerji ile İlgili Kamu Görüşünün Araştırılması. İşletme Bilimi Dergisi. 4(1). 67-77.

Yüksel, I. ve Dağdeviren, M. (2007). Using the Analytic Network Process (ANP) in a SWOT Analysis- A Case Study for a Textile Firm. Information Sciences. 177(16). 3364-3382. [https://doi.org/10.1016/j.ins.2007.01.001].

Yurt, S. ve Kadıoğlu, H. (2019). The Usage of Delphi Consensus Technique in Nursing. Journal of Education and Research in Nursing. 16(1). 48-53. [https://doi.org/10.5222/head. 2019.048]. 
